\begin{tabular}{|c|c|c|c|}
\hline$\bigcup_{\text {INESEG }}^{\text {INTERNATIONAL }}$ & $\begin{array}{r}\text { International } \\
\text { Res } \\
w w v\end{array}$ & $\begin{array}{l}\text { urnal of Health Services } \\
\text { rch and Policy } \\
\text { ergipark.org.tr/ijhsrp }\end{array}$ & \\
\hline $\begin{array}{l}\text { ENGINEERING } \\
\text { SCIENCE AND } \\
\text { EDUCATION GROUP }\end{array}$ & e-ISSN: 2602-3482 & DOI: 10.33457/ijhsrp.670014 & IJHSRP \\
\hline
\end{tabular}

Research Article

\title{
INVESTIGATION OF OECD COUNTRIES WITH MULTI-DIMENSIONAL SCALING ANALYSIS IN TERMS OF TRAFFIC ACCIDENT INDICATORS
}

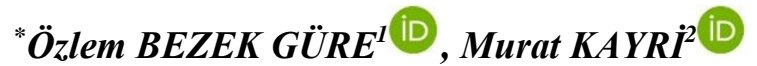 \\ ${ }^{1}$ Batman University, Health Services Vocational School \\ Medical Documentation and Secretarial Program, Batman, Turkey \\ ${ }^{2}$ Van Yüzüncü Yıl University, Faculty of Education, \\ Dept. of Computer and Instructional Technology Education, Van, Turkey \\ *Corresponding author: ozlem.bezekgure@ batman.edu.tr
}

\begin{abstract}
This study tries to compare similarities and differences in Organisation for Economic Cooperation and Development (OECD) countries in terms of traffic accidents utilizing Multidimensional Scale Analysis (MDS), and one of Multivariate Statistical Analysis Techniques. In the study, MDS analysis was carried out utilizing basic indicators such as the number of injuries, deaths and the number of accidents resulting in material damage in the traffic accidents that happened in 2017. As a result of the analysis, stress values and $R^{2}$ (correlation coefficient) values turned out to be 0.0000 and 1.0000 , respectively. That the stress value has resulted as zero shows that there is no inconsistency, and the fact that $R^{2}$ value has been found to be 1 indicates that the accuracy rate of this analysis is high and the values are in excellent coherence. According to results obtained from the analysis, it is seen that Malta and Liechtenstein, in particular, have appeared to be in a very different position from other countries when the countries are compared in terms of traffic accidents. When the matrix of the differences is examined; Turkey and Liechtenstein have seemed to be the two countries very different from each other. It is clear that traffic accidents, a global public health problem, have great impacts on individuals, societies and national economies. Particularly, it will be possible to decrease human and economic losses to minimum levels when the countries with similar traffic accident indicators come together, develop national and international projects and apply them.
\end{abstract}

Keywords: $O E C D$ countries, traffic accidents indicators, multivariate statistic, multi-dimensional scale

Received: January 3, 2020

Accepted: April 19, 2020

\section{Introduction}

In the developing world, traffic density and traffic accidents have increased due to the increasing number of vehicles, especially in parallel with the rapid increase in population in recent years. Traffic accident is an important problem in terms of their frequency, health aspect and economic consequences that affect society and individuals deeply. These accidents cause deaths and injuries as well as huge amounts of material damage. Although it is possible to compensate for economic losses, it is not possible to compensate for social losses. Due to these consequences of traffic accidents, human life is deeply affected. Traffic accidents, which are among the most important causes of death in the world, should be a priority issue in terms of public health [1-10]. 
Int. J. of Health Serv. Res. and Policy (2020) 5(1): 24-40

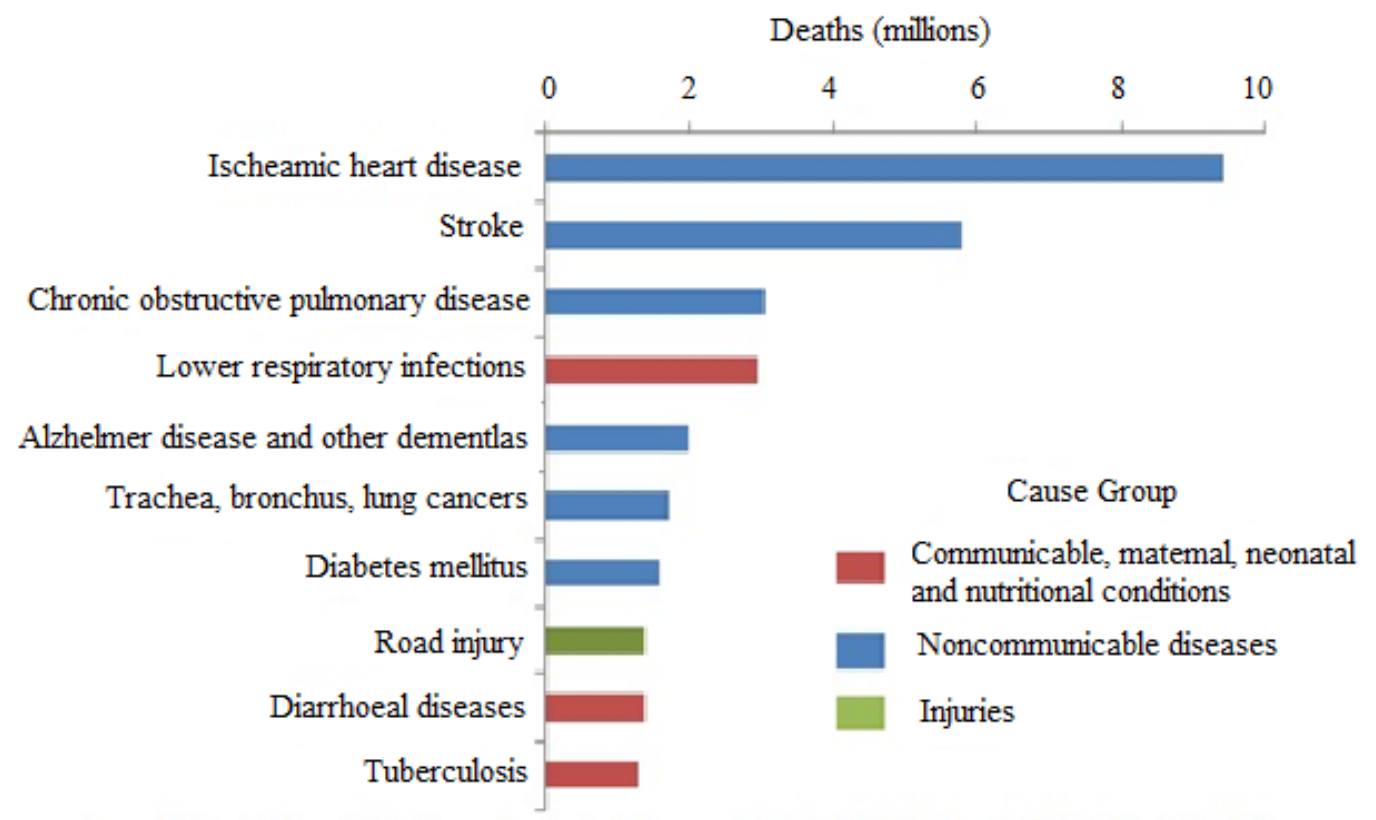

Figure 1. The most important death causes in the world 2000-2016 [11].

Figure 1 shows that traffic accidents take place in the $8^{\text {th }}$ rank among the most important causes of death in the world.

Approximately 1.35 million people lose their lives in traffic accidents in the world every year. Besides this, from 20 to 50 million people are injured and most of them are disabled. As for Turkey, about 10.000 people lose their lives every year due to traffic accidents [11]. Although the great majority of those who lose their lives are drivers and passengers, the share of pedestrians is also considerable. Injuries occurring as a result of traffic accidents cause significant economic losses for families and nations [4].

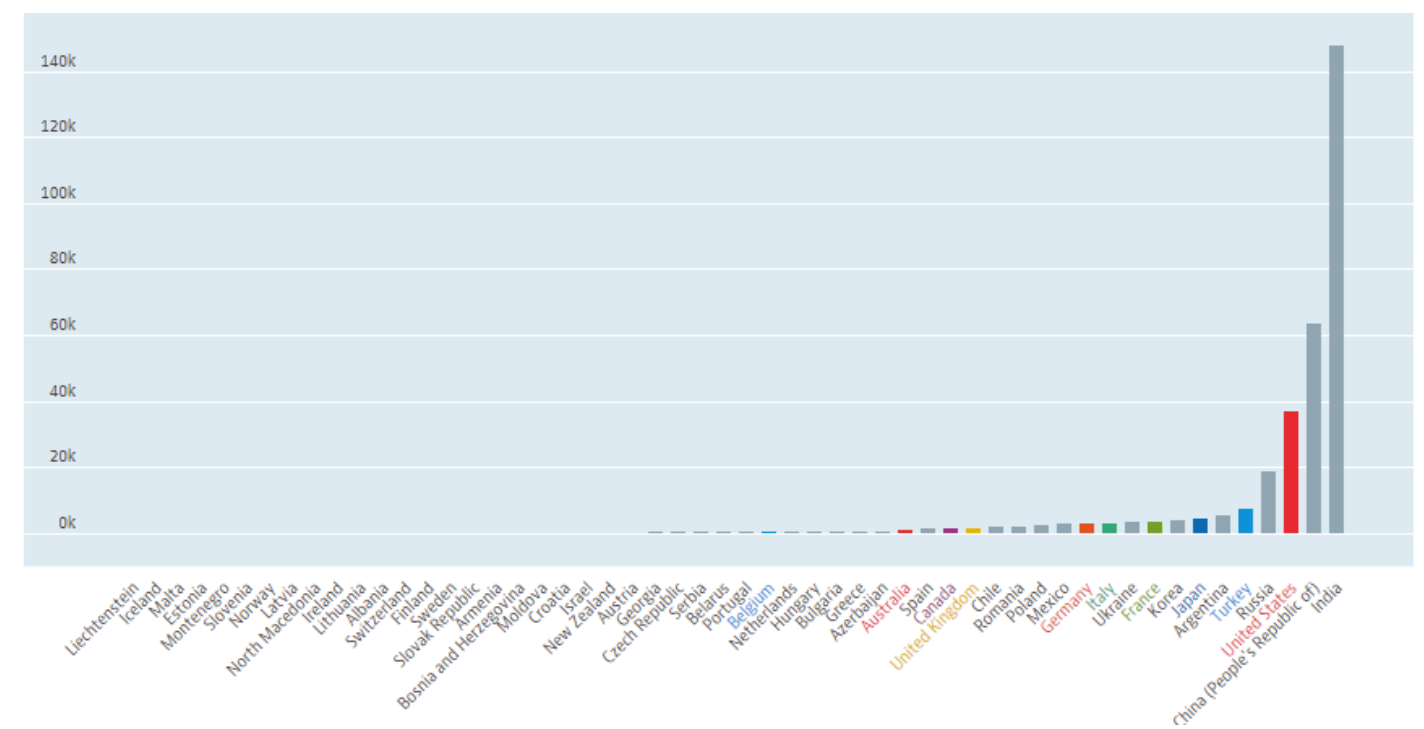

Figure 2. Distribution of traffic accidents in OECD countries in 2017 by the number of deaths [12]

Figure 2 shows that the countries which have the highest number of deaths in the traffic accidents in 2017 are India, China, the USA, Russia, Turkey, Argentina, Japan, and Korea, respectively. 


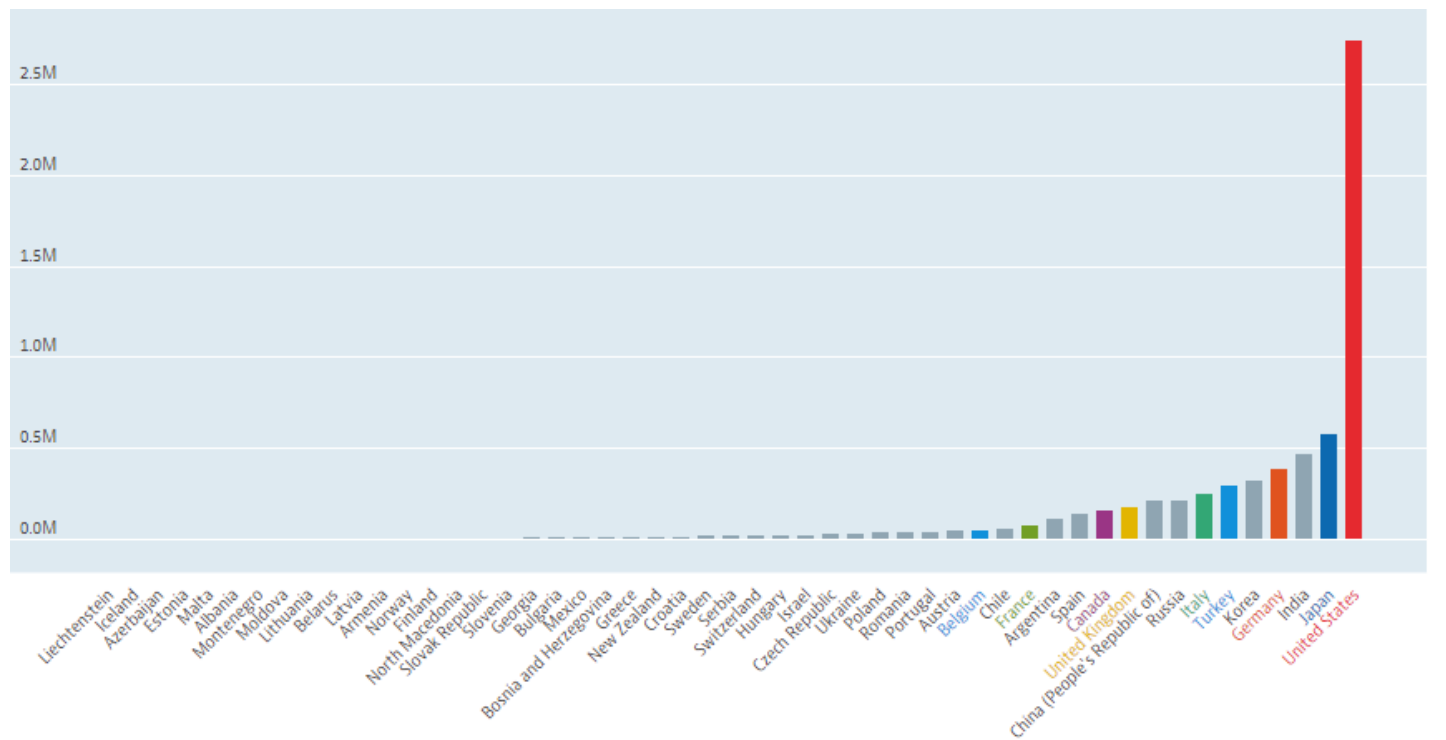

Figure 3. The distribution of the number of injured people in traffic accidents occurring in 2017 in OECD countries [12].

Figure 3 shows that the countries with the highest number of injured in traffic accidents in 2017 are the US, Japan, India, Germany, Korea, and Turkey; however, the least injured countries are Liechtenstein, Ireland, Estonia, Azerbaijan, and Malta.

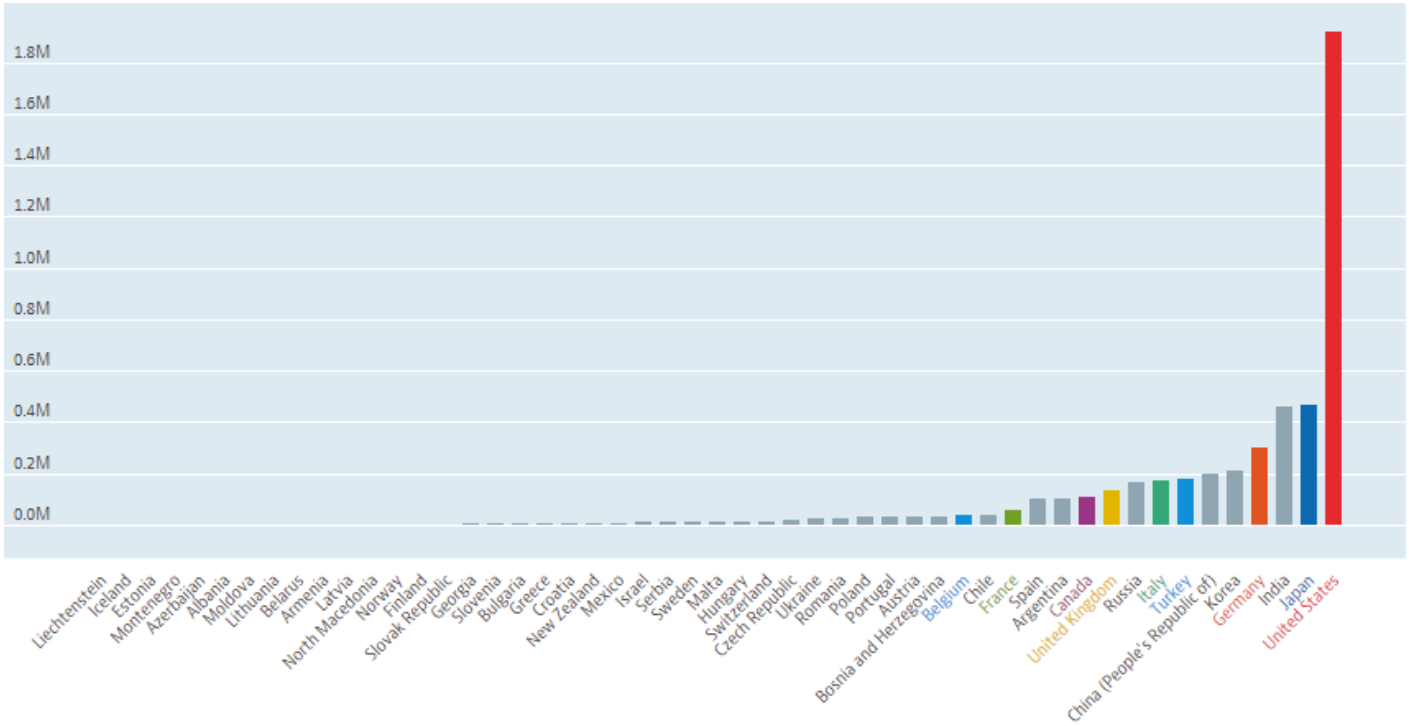

Figure 4. The distribution of the number of material damages in traffic accidents occurring in 2017 in OECD countries [12].

Figure 4 shows that the countries with the highest number of material damages are the US, Japan, India, Germany, Korea, China, and Turkey, while the countries with the least material damages are Liechtenstein, Ireland, Estonia and Azerbaijan, and Malta.

The motorway is mostly preferred in transportation in Turkey. Traffic accidents occurring on motorways in the world and Turkey are among the most important causes of death [13-16]. In 2017, a total of 1,202,716 traffic accidents occurred in Turkey. Of these accidents, 1,020,47 were materially damaged and 182,669 were fatal or injured traffic accidents. In 2017, 74.4\% of fatal or injured traffic accidents occurred in the city and $25.6 \%$ of them occurred outside the city. As a result of these accidents, 7,427 people were killed and 300,383 people were injured [14]. When compared with OECD countries 
Int. J. of Health Serv. Res. and Policy (2020) 5(1): 24-40

in terms of the number of deaths, injuries and the number of material damages in traffic accidents in 2017, Turkey, unfortunately, ranks at the top [13-14].

Traffic accident statistics in Turkey belonging to 2008-2017 are given in Table 1.

Table 1. Statistics of Traffic Accidents in Turkey 2008-2017

\begin{tabular}{|c|c|c|c|c|c|c|c|}
\hline \multirow[b]{2}{*}{ Years } & \multirow[b]{2}{*}{$\begin{array}{l}\text { The number of } \\
\text { total accidents }\end{array}$} & \multirow[b]{2}{*}{$\begin{array}{l}\text { The number of } \\
\text { positive, injury } \\
\text { accidents }\end{array}$} & \multirow[b]{2}{*}{$\begin{array}{l}\text { The number of } \\
\text { material damage } \\
\text { accidents }\end{array}$} & \multicolumn{3}{|c|}{ The number of deaths } & \multirow[b]{2}{*}{$\begin{array}{c}\text { The } \\
\text { number of } \\
\text { injured }\end{array}$} \\
\hline & & & & Total & $\begin{array}{l}\text { At the scene } \\
\text { of the } \\
\text { accident }\end{array}$ & $\begin{array}{c}\text { Post- } \\
\text { accident (1) }\end{array}$ & \\
\hline 2008 & 950,120 & 104,212 & 845,908 & 4,236 & 4,236 & - & 184,468 \\
\hline 2009 & $1,053,345$ & 111,121 & 942,224 & 4,324 & 4,324 & - & 201,380 \\
\hline 2010 & $1,105,201$ & 116,804 & 988,397 & 4,045 & 4,045 & - & 211,496 \\
\hline 2011 & $1,228,928$ & 131,845 & $1,097,083$ & 3,835 & 3,835 & - & 238,074 \\
\hline 2012 & $1,296,634$ & 153,552 & $1,143,082$ & 3,750 & 3,750 & - & 268,079 \\
\hline 2013 & $1,207,354$ & 161,306 & $1,046,048$ & 3,685 & 3,685 & - & 274,829 \\
\hline 2014 & $1,199,010$ & 168,512 & $1,030,498$ & 3,524 & 3,524 & - & 285,059 \\
\hline 2015 & $1,313,359$ & 183,011 & $1,130,348$ & 7,530 & 3,831 & 3,699 & 304,421 \\
\hline 2016 & $1,182,491$ & 185,128 & 997,363 & 7,300 & 3,493 & 3,807 & 300,812 \\
\hline 2017 & $1,202,716$ & 182,669 & $1,020,047$ & 7,427 & 3,534 & 3,893 & 300,383 \\
\hline
\end{tabular}

(1) It includes the people who died within thirty days due to accidents sent to the health centers after they were injured in traffic accidents [17].

Table 1 provided that between the years of 2008-2017, 11 million and 739 thousand and 158 traffic accidents occurred in Turkey. It can be observed that 49,656 people were killed, while 2,596,001 people were injured in the accidents happened. Also, it is understood that the number of deaths and injuries in traffic accidents occurring in recent years has nearly doubled compared to the previous years.

It is known that there are numerous studies dealing with traffic accidents in Turkey. Sungur et al. [3] investigated the problem of road security and traffic accidents in Turkey. Kuşkapan et al. [4] studied the traffic accidents caused by pedestrians in Turkey. Eşiyok et al. [8] handled the traffic accidents and their shortcomings in Turkey. Kırmızıoğlu and Tuydes Yaman [14] carried out a study about the literacy of drivers of traffic signs in Turkey. Çodur and Tortum [6] employed Artificial Neural Network (ANN) to estimate traffic accidents of the Erzurum province of Turkey. Çelik and Oktay [16] investigated the risk factors affecting injuries related to traffic accidents happened in Erzurum and Kars provinces of Turkey. Tortum et al. [5] tried to determine the effects of road factors on traffic security employing the Linear Regression method. Erdoğan [7] compared the traffic accidents and death rates in the provinces of Turkey using the Explorative Spatial Analysis method. Bektaş and Hınıs benefitted from the Logistic Regression method to determine factors having an influence on traffic accidents. Similarly, Karacasu et al. [13] tried to estimate the causes of traffic accidents applying Discriminant Analysis and Logistic Regression analysis to the data in Eskişehir province. Murat and Şekerler [19] tried to establish the reasons causing accidents by using Cluster analysis and modeling traffic accident data. Eygü [20] used Structural Equation Modelling in establishing the factors affecting traffic accidents. Likewise, Cansız [21] employed Logarithmic Regression and Artificial Neural Network methods in order to estimate death numbers in traffic accidents. Tercan and Beşdok [22] established the relations between parameters that affect traffic accidents and by using the Biplot method. Tercan et al. [23] modeled the data of traffic accidents by utilizing Evolutionary Data Clustering and Resilient Neural 
Int. J. of Health Serv. Res. and Policy (2020) 5(1): 24-40

Network methods. Uçar and Tatlıdil [24] made use of the Ordered Orbit Model so as to determine the factors affecting the severity of the accident. Ac1 and Y1lmaz [25] developed a model called Adaptive Network-Based Fuzzy Logic Inference System to find out the sensitive defect in traffic accidents with property damage. Ar1 [26] investigated the data of traffic accidents using the Log-Linear method. Güler [27] developed an Accident Analysis Segments model for traffic accidents. Doğrul et al. [28] investigated the data of traffic accidents with the help of Association Rules analysis, one of the data mining techniques. Similarly, Söylemez et al. [29] analysed the data of traffic accidents using Association Rules. While several different statistical analyses were used in the above-mentioned studies, no study was encountered where Multi-Dimensional Scaling analysis was employed. When literature scanning was carried out, the limited number of studies were found in terms of traffic accident indicators of OECD countries [30,31]. However, there are a number of studies where MDS analysis, the method used in this study as well, was used. Tokçuoğlu [32] and Gürçaylar Yenidoğan [33] measured the brand perception of university students employing MDS analysis. Büyüker İşler [34] benefited from MDS analysis to establish the process of brand locating of gas stations. Ekiyor [35] determined the perception maps of hospitals by employing MDS analysis. Ersöz [36] benefitted from MDS analysis to compare the health levels and health expenditures of Turkey and OECD countries. Acar [37] compared with OECD countries and Turkey in terms of basic indicators of the labor market with the help of the MDS method. Tüzüntürk [38] used the MDS method so that they could establish the similarities and differences of 81 provinces in Turkey in terms of crime types. Similarly, Etikan et al. [39] investigated judicial statistics of provinces through MDS. Ersöz et al. [40] benefitted from MDS analysis to compare biomass energy production in OECD countries. İhtiyaroğlu [41] investigated similarities and differences between provinces in Turkey in terms of student placement in the associate degree, undergraduate and open education faculties of universities. Finally, Akın and Eren [42] benefitted from the MDS method to compare education indicators of OECD countries.

\section{Materials and Methods}

MDS analysis is a multivariate statistical analysis method that shows the relationships between objects by reducing the size, revealing the positions of these objects in one or multidimensional space based on the distances between $n$ objects or units determined according to the $\mathrm{p}$ variable [34-35,37-38, 43-44]. In the graphical representation, points representing similar objects in space are close to each other, dissimilar ones are far from each other [47]. Although MDS analysis, which is considered as a data reduction analysis, was developed as an alternative to Factor Analysis, there are differences between the two methods. While applying factor analysis, some assumptions such as normality, linearity etc. should be provided, while the MDS analysis does not have any assumptions. In factor analysis, the variance-covariance matrix or correlation matrix is used to see the relationships between variables, while the distance matrix is used to see the relationships between units in the MDS [32, 36-37, 44,48-49]. MDS is used when the relationships between units or objects are not absolutely known and the distance matrix can be obtained [50]. The MDS analysis provides an analytical layout that shows the relationship structure of the data in multi-dimensional space very close to the original position in order to better understand the similarities/dissimilarities between the variables [38,51]. MDS analysis was first developed by Householder and Young in the 1930s and later developed by Tagerson et al. [31,36]. MDS was born in the field of psychometry, its use was not limited to psychology, though. It is widely used in fields such as medicine, science and social sciences, education, economics, archaeology and so on 
Int. J. of Health Serv. Res. and Policy (2020) 5(1): 24-40

[27,33]. MDS analysis is frequently used in the analysis of data such as religious beliefs, behaviours, and expectations of individual preferences [36,52-53].

The techniques applied according to the scale and data type used in the MDS analysis differ. In this analysis, the Ordinal Scale, Interval Scale, and Ratio scale can be applied to various data types [34].

The data to be used in MDS analysis are multivariate data. Data with many variables including the number of variables $p$ and number of observations (measurements) $n$ are shown as follows:

$$
X=\left[\begin{array}{ccc}
x_{11} & x_{12} \ldots \ldots & x_{1 n} \\
x_{21} & x_{22} \ldots \ldots & x_{2 n} \\
\vdots & \vdots \ldots & \vdots
\end{array}\right]=\left[x_{1}, x_{2}, \ldots . x_{n}\right]_{p x n}
$$

This matrix is called a data matrix. Here, for $\mathrm{j}=1,2, \ldots, \mathrm{p} ; \mathrm{i}=1,2, \ldots, \mathrm{n}, \mathrm{i}^{\text {th }}$ is the observation result over ji $\mathrm{x}: \mathrm{j}^{\text {th }}$ variable. As the variables can be in different scale types and different measurement units, the analysis results may be affected. Therefore, it is recommended to convert the values to score values or standard values to reduce the effects [43]. In the data sets obtained with range and proportional scale; Euclidean distance, Square Euclidean distance, Chebychef, City-Block, Minkowski distances can be selected. In MDS analysis, the most important point is to determine the distance measure; and the distance acquisition methods appropriate to the data types should be preferred. In binary scale data types; Euclidean distance, Square Euclidean distance, Pattern difference, Lance Williams distance can be preferred [43].

In MDS analysis, the most known and prevalently used distance measurement is Euclid distance. This distance is calculated by taking the square root of the sum of the squares of the differences between the observation vectors. The City-Block distance, also known as the Manhattan distance, is equal to the sum of the absolute differences between the units' variables. As this distance measure is used, the effect of the differences decreases since the difference is not squared. Chebyshev distance is a metric distance measure that takes the difference in size with the maximum difference between the two observation vectors as the distance between the two observation vectors. Minkowski distance is a general and metric measure and is one of the distance functions used for quantitative data [44]. One of the most important problems when performing the MDS analysis is to decide the number of dimensions. The number of dimensions in which the resulting graphical representation is easier to understand and interpret should be preferred. Usually, two and three-dimensional ones are used. The stress value is used to determine whether the number of dimensions to be used is appropriate.

Stress statistics are used to determine the number of dimensions as a result of size reduction. Stress statistics converge to a certain value as a result of iterations. The number of dimensions belonging to the converged value can be selected. Apart from this method, the number of dimensions can be decided by using the eigenvalues of the positive half-defined B matrix obtained by the product of the raw data matrix and the transposition [47].

Compliance between original distances and display distances is measured by Kruskal stress statistics. Stress measurement is calculated via the following formula [43].

$$
S=\frac{\left[\sum_{i<k}\left(d_{i k}-\widehat{d}_{i k}\right)^{2}\right]^{\frac{1}{2}}}{\sum_{i<k}\left(d_{i k}\right)^{2}}
$$

Kruskal tolerance ratios are used to interpret the configuration distances according to the magnitude of stress values. These tolerance ratios are as follows: 
Int. J. of Health Serv. Res. and Policy (2020) 5(1): 24-40

Table 2. Consistency Level according to Stress Values

\begin{tabular}{|l|l|}
\hline Stress Value & Consistency \\
\hline$\geq 0.20$ & Inconsistency representation \\
\hline $0.10-<0.20$ & Low consistency \\
\hline $0.05-<0.10$ & Good consistency \\
\hline $0.025-<0.05$ & Excellent consistency \\
\hline $0.000-<0.025$ & Full consistency \\
\hline
\end{tabular}

A high-stress value indicates a high inconsistency; while a low-stress value indicates a low inconsistency [38, 43, 54].

In MDS, the square of the correlation coefficient $\left(R^{2}\right)$ is often used as a consistency index. $R^{2}$ is a measure determining how much MDS model is compatible with the data. If $\mathrm{R}^{2}$ is 1 , it is understood that the compatibility is complete. In the analysis, it is generally acceptable that $\mathrm{R}^{2}$ is greater than $60 \%$, but it can be said that as $\mathrm{R}^{2}$ value gets bigger, the consistency becomes better [47].

Depending on the type of MDS analysis data, metric MDS and non-metric MDS are used. Metric MDS is applied to data based on quantitative and metric distances. It is used since values obtained through measurement. In this scaling, representation and data distances are calculated by linear or polynomial function method. Non-metric MDS, on the other hand, is applied to score, order and categorical data. In non-metric scaling, the representation and data distances are calculated by the monotonic function method [43]. In practice, non-metric MDS is more preferred because it requires less assumption. Although it is known that the results obtained from the two methods are very close to each other when metric and non-metric MDS is applied to the same data set in the MDS, the approach appropriate to the distance matrix should be preferred [47].

\section{Results}

The aim of this study is to compare the OECD countries with the Multidimensional Scaling analysis in terms of traffic accident indicators and to determine the similarities or differences of the countries and to reveal the variables that affect the differentiation. Traffic Accident Indicators taking place in "Road Accident" database published by OECD Data were used in the study [12]. These indicators include the number of injuries in traffic accidents, the number of fatalities and the number of accidents with material damage. In this study, data from 39 countries were used since not all countries could be evaluated due to the lack of some data from OECD countries. MDS analysis, which was conducted to find similarities and differences between OECD countries in terms of traffic accident indicators, was applied to the SPSS 21.0 package program in two dimensions since it is easier to understand graphically.

Within the context of the study, the main indicators of 2017 traffic accidents of 39 OECD member countries were used. Accident Statistics of OECD Countries for 2017 are given in Table 3. 
Int. J. of Health Serv. Res. and Policy (2020) 5(1): 24-40

Table 3. Accident Statistics of OECD Countries for 2017

\begin{tabular}{|c|c|c|c|c|}
\hline Country & Year & $\begin{array}{c}\text { Number of } \\
\text { injured }\end{array}$ & $\begin{array}{l}\text { Number of accidents } \\
\text { with material damage }\end{array}$ & $\begin{array}{c}\text { Number of } \\
\text { deaths }\end{array}$ \\
\hline Argentina & 2017 & 113173 & 102623 & 5420 \\
\hline Armenia & 2017 & 5179 & 3535 & 279 \\
\hline Azerbaijan & 2017 & 1719 & 1833 & 750 \\
\hline Belgium & 2017 & 48451 & 38020 & 609 \\
\hline Bulgaria & 2017 & 8680 & 6888 & 682 \\
\hline Switzerland & 2017 & 21413 & 17799 & 230 \\
\hline Czech Republic & 2017 & 27079 & 21263 & 577 \\
\hline Germany & 2017 & 390312 & 302656 & 3180 \\
\hline Estonia & 2017 & 1725 & 1406 & 48 \\
\hline Finland & 2017 & 5576 & 4752 & 238 \\
\hline France & 2017 & 73384 & 58613 & 3448 \\
\hline The UK & 2017 & 178321 & 136063 & 1856 \\
\hline Georgia & 2017 & 8461 & 6079 & 517 \\
\hline Greece & 2017 & 12925 & 10647 & 731 \\
\hline Croatia & 2017 & 14608 & 10939 & 331 \\
\hline Hungry & 2017 & 21451 & 16489 & 625 \\
\hline India & 2017 & 470975 & 464910 & 147913 \\
\hline Iceland & 2017 & 1371 & 939 & 16 \\
\hline Italy & 2017 & 246750 & 174933 & 3378 \\
\hline Japan & 2017 & 580113 & 472165 & 4431 \\
\hline Korea & 2017 & 322829 & 216335 & 4185 \\
\hline Lichtenstein & 2017 & 87 & 436 & 2 \\
\hline Latvia & 2017 & 3567 & 3059 & 136 \\
\hline Latonia & 2017 & 4818 & 3874 & 191 \\
\hline Moldova & 2017 & 2928 & 2479 & 302 \\
\hline Mexico & 2017 & 8905 & 11873 & 2919 \\
\hline Macedonia & 2017 & 6224 & 4019 & 155 \\
\hline Malta & 2017 & 1854 & 15003 & 19 \\
\hline Montenegro Republic & 2017 & 2648 & 1831 & 63 \\
\hline Norway & 2017 & 5262 & 4086 & 106 \\
\hline New Zealand & 2017 & 13892 & 11126 & 378 \\
\hline Poland & 2017 & 39466 & 32760 & 2831 \\
\hline Romania & 2017 & 40211 & 31106 & 1951 \\
\hline Russia & 2017 & 215374 & 169432 & 19088 \\
\hline Slovakia & 2017 & 21139 & 14691 & 276 \\
\hline Slovenia & 2017 & 6884 & 5638 & 104 \\
\hline Serbia & 2017 & 7901 & 6185 & 578 \\
\hline Sweden & 2017 & 19662 & 14849 & 252 \\
\hline Turkey & 2017 & 300383 & 182669 & 7427 \\
\hline
\end{tabular}

(OECD DATA, 2017) [12].

In Table 3, the data of 39 OECD member countries take place. The data of the other countries are not included in the assessment as they do not take place in the database. When Table 3 is examined, it is seen that Japan and India are the countries that have the highest number of material damage accidents and that Argentina, Japan, Korea, India, Russia, and Turkey are the countries that have the highest number of deaths. On the other hand, it is understood that Lichtenstein is the country that has the least values in terms of traffic indicators. 
Int. J. of Health Serv. Res. and Policy (2020) 5(1): 24-40

Kruskal-Stress Statistics and $\mathrm{R}^{2}$ values that are obtained as a result of the MDS analysis conducted to compare OECD countries in terms of traffic accidents are given below in Table 4.

Table 4. Results of Multidimensional Scaling analysis

\begin{tabular}{|l|l|l|}
\hline \multicolumn{3}{|c|}{ Stress Statistic Results of Young } \\
\hline Iteration & S-stress & Improvement \\
\hline 1 & .0000 & \\
\hline
\end{tabular}

When Table 4 is examined, it can be seen that iteration was halted since stress statistics for $\mathrm{k}=2$ had a value of 0.00000 in the first iteration according to Stress Statistics of Young. Stress and $\mathrm{R}^{2}$ were obtained as 0.00000 and 1.00000 , respectively. In the study, if the stress value is zero, there is no inconsistency, and if the $\mathrm{R}^{2}$ value is 1 , it means that the accuracy rate of this analysis is high and the values are in perfect agreement.

Table 5. Stimulating coordinates

\begin{tabular}{|c|c|c|c|c|}
\hline Order No & Country & Countries & 1.Dimension & 2. Dimension \\
\hline 1 & ARG & Argentina & .2613 & .3050 \\
\hline 2 & ARM & Armenia & -.9753 & -.3349 \\
\hline 3 & AZE & Azerbaijan & 1.2845 & .5706 \\
\hline 4 & BEL & Belgium & -.3425 & .0422 \\
\hline 5 & BGR & Bulgaria & -.3859 & .0199 \\
\hline 6 & CHE & Switzerland & -.0916 & .1619 \\
\hline 7 & CZE & Czech Republic & -.3267 & .0503 \\
\hline 8 & DEU & Germany & -.3842 & .0208 \\
\hline 9 & EST & Estonia & -.2208 & .1022 \\
\hline 10 & FIN & Finland & .0096 & .2059 \\
\hline 11 & FRA & France & -.2710 & .0780 \\
\hline 12 & GBR & The UK & -.4381 & -.0075 \\
\hline 13 & GEO & Georgia & -.7875 & -.2107 \\
\hline 14 & GRC & Greece & -.1874 & .1181 \\
\hline 15 & HRV & Croatia & -.5179 & -.0510 \\
\hline 16 & HUN & Hungry & -.4484 & -.0131 \\
\hline 17 & IND & India & .6414 & .4284 \\
\hline 18 & ISL & Iceland & -.8380 & -.2430 \\
\hline 19 & ITA & Italy & -.736 & -.1790 \\
\hline 20 & JPN & Japan & -.1856 & .1189 \\
\hline 21 & KOR & Korea & -.9364 & -.3082 \\
\hline 22 & LIE & Lichtenstein & 5.2494 & -.3212 \\
\hline 23 & LTU & Latvia & -.0260 & .1907 \\
\hline 24 & LVA & Latonia & -.2730 & .0770 \\
\hline 25 & MDA & Moldova & -.1302 & .1445 \\
\hline 26 & MEX & Mexico & -2.0472 & .6378 \\
\hline 27 & MKD & Macedonia & -1.0818 & -.4103 \\
\hline 28 & MLT & Malta & 5.5832 & -.5687 \\
\hline 29 & MNE & Montenegro Republic & -.8670 & -.2619 \\
\hline 30 & NOR & Norway & -.3971 & .0141 \\
\hline 31 & NZL & New Zealand & -.2576 & .0845 \\
\hline 32 & POL & Poland & -.0979 & .1591 \\
\hline 33 & ROU & Romania & -.4464 & -.0120 \\
\hline 34 & RUS & Russia & -.3177 & .0548 \\
\hline 35 & SVK & Slovakia & -.1593 & .1312 \\
\hline 36 & SVN & Slovenia & -.3589 & .0339 \\
\hline 37 & SRB & Serbia & -.8368 & -.2423 \\
\hline 38 & SWE & Sweden & -.4797 & -.0300 \\
\hline 39 & TUR & Turkey & -1.2732 & -.5559 \\
\hline
\end{tabular}


Int. J. of Health Serv. Res. and Policy (2020) 5(1): 24-40

When Table 5 is analysed, it is seen that Liechtenstein and Malta are the most important disintegrants in this dimension as the countries with the highest positive value in the first dimension. That is to say, it is understood that these countries are perceived to be similar in terms of the number of deaths, number of injuries and number of daily accidents in traffic accidents. Also; it is seen that Azerbaijan is different from other countries with a positive value above 1 and that Mexico, Macedonia, and Turkey seem to be the most diverse countries because they have high negative values above 1 . In the second dimension, countries do not have positive load values above 1. However, Mexico, with a value of 0.6378 as the positive value closest to 1 , can be considered the most important separator for this dimension.

The difference matrix obtained after the excitation coordinate table is given below. In this matrix, it can be said that countries with values close to 0 are similar and countries with values above 1 are different from the others. Since this matrix, where the distances between the 39 countries are calculated, is large, it is given below part by part.

Table 6. Differences matrix

\begin{tabular}{|c|c|c|c|c|c|c|c|c|c|c|c|c|c|}
\hline & ARG & ARM & AZE & BEL & BGR & CHE & CZE & DEU & EST & FIN & FRA & GBR & GEO \\
\hline ARG & 0.000 & & & & & & & & & & & & \\
\hline ARM & .682 & 0.000 & & & & & & & & & & & \\
\hline$\overline{\mathrm{AZE}}$ & .517 & 1.199 & 0.000 & & & & & & & & & & \\
\hline BEL & .322 & .360 & .839 & 0.000 & & & & & & & & & \\
\hline BGR & .346 & .336 & .863 & .024 & 0.000 & & & & & & & & \\
\hline CHE & .187 & .495 & .704 & .136 & .160 & 0.000 & & & & & & & \\
\hline CZE & .314 & .368 & .831 & .009 & .032 & .127 & 0.000 & & & & & & \\
\hline DEU & .345 & .337 & .862 & .023 & .002 & .159 & .032 & 0.000 & & & & & \\
\hline EST & .256 & .426 & .773 & .066 & .090 & .069 & .058 & .089 & 0.000 & & & & \\
\hline FIN & .133 & .549 & .650 & .190 & .214 & .054 & .181 & .213 & .123 & 0.000 & & & \\
\hline FRA & .283 & .399 & .800 & .039 & .063 & .097 & .030 & .062 & .027 & .151 & 0.000 & & \\
\hline GBR & .375 & .307 & .892 & .053 & .029 & .188 & .061 & .030 & .119 & .242 & .092 & 0.000 & \\
\hline GEO & .572 & .110 & 1.090 & .250 & .226 & .386 & .259 & .227 & .316 & .440 & .289 & .197 & 0.000 \\
\hline GRC & .238 & .444 & .755 & .084 & .108 & .051 & .076 & .107 & .018 & .105 & .045 & .137 & $\ldots$ \\
\hline HRV & .419 & .263 & .936 & .097 & .073 & .233 & .106 & .074 & .163 & .287 & .136 & .044 & $\ldots$ \\
\hline HUN & .381 & .301 & .898 & .058 & .034 & .194 & .067 & .035 & .124 & .248 & .097 & .006 & $\ldots$ \\
\hline IND & .196 & .878 & .322 & .518 & .542 & .382 & .509 & .541 & .452 & .328 & .479 & .570 & $\ldots$ \\
\hline ISL & .602 & .080 & 1.119 & .279 & .256 & .415 & .288 & .256 & .346 & .469 & .318 & .227 & $\ldots$ \\
\hline ITA & .543 & .139 & 1.060 & .221 & .197 & .357 & .229 & .198 & .287 & .411 & .260 & .168 & $\ldots$ \\
\hline JPN & .237 & .445 & .754 & .085 & .109 & .051 & .077 & .108 & .019 & .105 & .046 & .138 & $\ldots$ \\
\hline KOR & .659 & .023 & 1.176 & .337 & .313 & .473 & .345 & .314 & .403 & .527 & .376 & .284 & $\ldots$ \\
\hline LIE & 2.443 & 3.120 & 1.933 & 2.762 & 2.786 & 2.628 & 2.754 & 2.785 & 2.697 & 2.574 & 2.724 & 2.815 & $\ldots$ \\
\hline LTU & .151 & .531 & .669 & .171 & .195 & .035 & .162 & .194 & .105 & .019 & .132 & .223 & $\ldots$ \\
\hline LVA & .284 & .398 & .801 & .038 & .062 & .098 & .029 & .061 & .028 & .152 & .002 & .091 & $\ldots$ \\
\hline MDA & .207 & .475 & .724 & .115 & .139 & .021 & .106 & .138 & .049 & .075 & .076 & .168 & $\ldots$ \\
\hline MEX & .888 & 1.570 & .371 & 1.210 & 1.234 & 1.075 & 1.202 & 1.233 & 1.144 & 1.021 & 1.171 & 1.263 & $\ldots$ \\
\hline MKD & .746 & .064 & 1.263 & .423 & .399 & .559 & .432 & .400 & .490 & .613 & .462 & .371 & $\ldots$ \\
\hline MLT & 2.617 & 3.279 & 2.123 & 2.929 & 2.952 & 2.797 & 2.921 & 2.951 & 2.865 & 2.745 & 2.891 & 2.980 & $\ldots$ \\
\hline MNE & .618 & .064 & 1.136 & .296 & .272 & .432 & .305 & .273 & .362 & .486 & .335 & .244 & $\ldots$ \\
\hline NOR & .352 & .330 & .869 & .030 & .006 & .166 & .039 & .007 & .096 & .220 & .069 & .023 & $\ldots$ \\
\hline NZL & .276 & .406 & .793 & .046 & .070 & .089 & .038 & .069 & .020 & .144 & .007 & .099 & $\ldots$ \\
\hline POL & .190 & .492 & .707 & .132 & .156 & .003 & .124 & .155 & .066 & .057 & .093 & .185 & $\ldots$ \\
\hline $\mathrm{ROU}$ & .379 & .303 & .897 & .057 & .033 & .193 & .066 & .034 & .123 & .247 & .096 & .005 & $\ldots$ \\
\hline RUS & .309 & .373 & .826 & .014 & .037 & .122 & .005 & .036 & .053 & .176 & .025 & .066 & $\ldots$ \\
\hline SVK & .223 & .459 & .740 & .099 & .123 & .036 & .091 & .122 & .033 & .090 & .060 & .152 & $\ldots$ \\
\hline SVN & .331 & .351 & .848 & .009 & .015 & .145 & .018 & .014 & .075 & .199 & .048 & .044 & $\ldots$ \\
\hline SRB & .601 & .081 & 1.118 & .279 & .255 & .414 & .287 & .256 & .345 & .468 & .318 & .226 & $\ldots$ \\
\hline SWE & .398 & .284 & .915 & .076 & .052 & .211 & .084 & .053 & .142 & .265 & .115 & .023 & $\ldots$ \\
\hline $\begin{array}{l}\text { TUR } \\
\end{array}$ & .862 & .180 & 1.380 & .540 & .516 & .676 & .549 & .517 & .606 & .730 & .579 & .488 & \\
\hline
\end{tabular}


Int. J. of Health Serv. Res. and Policy (2020) 5(1): 24-40

Its continuation

Table 6. Differences Matrix

\begin{tabular}{|c|c|c|c|c|c|c|c|c|c|c|c|c|c|c|}
\hline & GEO & GRC & HRV & HUN & IND & ISL & ITA & JPN & KOR & LIE & LTU & LVA & MDA & MEX \\
\hline GEO & 0.000 & & & & & & & & & & & & & \\
\hline$\overline{\text { GRC }}$ & .334 & 0.000 & & & & & & & & & & & & \\
\hline HRV & .153 & .181 & 0.000 & & & & & & & & & & & \\
\hline HUN & .192 & .143 & .039 & 0.000 & & & & & & & & & & \\
\hline IND & .768 & .434 & .615 & .576 & 0.000 & & & & & & & & & \\
\hline ISL & .029 & .364 & .182 & .221 & .797 & 0.000 & & & & & & & & \\
\hline ITA & .029 & .305 & .124 & .163 & .739 & .058 & 0.000 & & & & & & & \\
\hline JPN & .335 & .002 & .182 & .143 & .433 & .364 & .306 & 0.000 & & & & & & \\
\hline KOR & .087 & .421 & .240 & .279 & .855 & .058 & .116 & .422 & 0.000 & & & & & \\
\hline LIE & 3.011 & 2.679 & 2.859 & 2.820 & 2.250 & 3.040 & 2.982 & 2.678 & 3.097 & 0.000 & & & & \\
\hline LTU & .421 & .086 & .268 & .229 & .347 & .450 & .392 & .086 & .508 & 2.593 & 0.000 & & & \\
\hline LVA & .288 & .046 & .135 & .096 & .480 & .317 & .259 & .047 & .375 & 2.725 & .133 & 0.000 & & \\
\hline MDA & .365 & .031 & .212 & .173 & .403 & .394 & .336 & .030 & .452 & 2.648 & .056 & .077 & 0.000 & \\
\hline MEX & 1.461 & 1.126 & 1.307 & 1.269 & .693 & 1.490 & 1.431 & 1.125 & 1.547 & 1.571 & 1.040 & 1.172 & 1.095 & 0.000 \\
\hline MKD & .173 & .508 & .326 & .365 & .941 & .144 & .202 & .508 & .086 & 3.183 & .594 & .461 & .538 & $\ldots$ \\
\hline MLT & 3.172 & 2.847 & 3.023 & 2.986 & 2.429 & 3.200 & 3.144 & 2.846 & 3.257 & 1.060 & 2.763 & 2.892 & 2.817 & $\ldots$ \\
\hline MNE & .046 & .380 & .199 & .238 & .814 & .017 & .075 & .381 & .041 & 3.057 & .467 & .334 & .411 & $\ldots$ \\
\hline NOR & .220 & .114 & .067 & .028 & .548 & .249 & .191 & .115 & .307 & 2.792 & .201 & .068 & .145 & $\ldots$ \\
\hline NZL & .296 & .038 & .143 & .104 & .472 & .326 & .267 & .039 & .383 & 2.717 & .125 & .008 & .069 & $\ldots$ \\
\hline POL & .382 & .048 & .229 & .191 & .386 & .412 & .353 & .047 & .469 & 2.631 & .038 & .094 & .017 & $\ldots$ \\
\hline ROU & .193 & .142 & .040 & .001 & .575 & .222 & .164 & .142 & .280 & 2.819 & .228 & .095 & .172 & $\ldots$ \\
\hline RUS & .264 & .071 & .110 & .072 & .504 & .293 & .234 & .072 & .350 & 2.749 & .157 & .024 & .102 & $\ldots$ \\
\hline SVK & .350 & .015 & .196 & .158 & .418 & .379 & .320 & .014 & .436 & 2.664 & .071 & .061 & .016 & $\ldots$ \\
\hline SVN & .241 & .093 & .088 & .049 & .527 & .270 & .212 & .094 & .328 & 2.771 & .180 & .047 & .124 & $\ldots$ \\
\hline SRB & .029 & .363 & .182 & .220 & .797 & .004 & .058 & .364 & .058 & 3.039 & .449 & .317 & .394 & $\ldots$ \\
\hline SWE & .174 & .160 & .021 & .017 & .594 & .204 & .145 & .161 & .261 & 2.837 & .246 & .114 & .191 & $\ldots$ \\
\hline TUR & .290 & .625 & .443 & .482 & 1.058 & .261 & .319 & .625 & .203 & 3.300 & .711 & .578 & .655 & $\ldots$ \\
\hline
\end{tabular}

Its continuation

Table 6. Differences Matrix

\begin{tabular}{|l|r|r|r|r|r|r|r|r|r|r|r|r|r|r|}
\hline & MEX & MKD & MLT & MNE & NOR & NZL & POL & ROU & RUS & SVK & SVN & SRB & SWE & TUR \\
\hline MEX & 0.000 & & & & & & & & & & & & & \\
\hline MKD & 1.634 & 0.000 & & & & & & & & & & & & \\
\hline MLT & 1.776 & 3.341 & 0.000 & & & & & & & & & & & \\
\hline MNE & 1.507 & .127 & 3.217 & 0.000 & & & & & & & & & & \\
\hline NOR & 1.240 & .393 & 2.958 & .266 & 0.000 & & & & & & & & & \\
\hline NZL & 1.164 & .470 & 2.884 & .342 & $\mathbf{. 0 7 6}$ & 0.000 & & & & & & & & \\
\hline POL & 1.078 & .556 & 2.801 & .429 & .162 & $\mathbf{. 0 8 6}$ & 0.000 & & & & & & & \\
\hline ROU & 1.268 & .366 & 2.984 & .239 & $\mathbf{. 0 2 7}$ & .103 & .190 & 0.000 & & & & & & \\
\hline RUS & 1.197 & .437 & 2.916 & .310 & $\mathbf{. 0 4 3}$ & $\mathbf{. 0 3 3}$ & .119 & $\mathbf{. 0 7 1}$ & 0.000 & & & & & \\
\hline SVK & 1.111 & .523 & 2.832 & .396 & .129 & $\mathbf{. 0 5 3}$ & $\mathbf{. 0 3 3}$ & .157 & $\mathbf{. 0 8 6}$ & 0.000 & & & & \\
\hline SVN & 1.219 & .414 & 2.938 & .287 & $\mathbf{. 0 2 1}$ & $\mathbf{. 0 5 5}$ & .141 & $\mathbf{. 0 4 8}$ & $\mathbf{. 0 2 3}$ & .108 & 0.000 & & & \\
\hline SRB & 1.489 & .145 & 3.200 & $\mathbf{. 0 1 8}$ & .249 & .325 & .411 & .221 & .292 & .378 & .270 & 0.000 & & \\
\hline SWE & 1.286 & .348 & 3.002 & .221 & $\mathbf{. 0 4 6}$ & .122 & .208 & $\mathbf{. 0 1 8}$ & $\mathbf{. 0 8 9}$ & .175 &. $\mathbf{0 6 7}$ & .203 & 0.000 & \\
\hline TUR & 1.751 & .117 & 3.455 & .244 & .510 & .586 & .673 & .483 & .554 & .640 & .531 & .262 & .465 & 0.000 \\
\hline
\end{tabular}

It is seen that countries display similarities in terms of traffic accidents. They have values close to 0 in the differences matrix given above. For example; Armenia has close values as Iceland, Korea, 
Int. J. of Health Serv. Res. and Policy (2020) 5(1): 24-40

Macedonia, Montenegro Republic, and Serbia. Belgium has close values as Bulgaria, Czech Republic, Germany, Estonia, France, The UK, Greece, Croatia, Hungry, Japan, Latvia, Norway, New Zealand, Romania, Russia, Slovenia, Slovakia, and Sweden. Bulgaria has close values with Czech Republic, Germany, Estonia, France, the UK, Croatia, Hungry, Latvia, Norway, New Zealand, Romania, Russia, Slovenia, Sweden, and Switzerland has close values as Estonia, Finland, France, Greece and Japan; and Latvia, Latonia, Moldova, New Zealand, Poland, and Slovakia. Czech Republic has close values as Germany, Estonia, France, the UK, Greece, Japan, Latonia, Norway, New Zealand, Romania, Russia, Slovenia, Slovakia, and Sweden. Germany has close values as Estonia, France, the UK, Croatia, Hungry, Latonia, Norway, New Zealand, Romania, Russia, Slovenia, and Sweden Estonia has close values as France, Greece, Japan, Latonia Moldova, Norway, New Zealand, Poland, Slovenia, and Slovakia. Finland has close values as Latvia, Moldova, Poland, and Slovenia. France has close values as Greece, the UK, Hungry, Japan, Latonia Moldova, New Zealand, Poland, Romania, Russia, Slovakia, Slovenia, and Sweden the UK has close values as Croatia, Hungry, Latonia, Norway, Romania, Russia, and Slovenia. Georgia has close values as Iceland, Italy, Montenegro Republic, and Serbia. Greece has close values as Japan, Latonia, Latvia, Moldova, New Zealand, Poland, Russia Slovenia, Slovakia and Croatia and Hungry, Norway, Romania, Slovenia, and Sweden. Hungry has close values as Latvia, Norway, Romania, Russia, Slovenia, and Sweden. Iceland has close values as Italy and Korea, Montenegro Republic and Serbia. Italy has close values as the Montenegro Republic and Serbia. Japan has close values as Montenegro Republic, New Zealand, Poland, Russia Slovenia, and Slovakia. Korea has close values as Macedonia, Montenegro Republic, and Serbia. Latvia has close values as Moldova. Latonia has close values as Montenegro Republic, Norway, New Zealand, Poland, Romania, Russia, Slovakia, and Slovenia. Moldova has close values as New Zealand, Poland and Slovakia; and the Montenegro Republic with Serbia; and Norway with New Zealand, Romania, Slovenia, and Sweden. Romania has close values as Russia, Slovenia, and Sweden. Russia has close values as Slovakia, Slovenia, and Sweden.

When the differences matrix is analysed, it is understood that Turkey and Malta are the most diverse countries. On the other hand, it is seen that Lichtenstein and Turkey; Sweden, Korea, Georgia and Macedonia, and furthermore Malta and Georgia, Armenia, Croatia, Iceland, and Korea are countries that are very different from each other due to the high difference values. 
Int. J. of Health Serv. Res. and Policy (2020) 5(1): 24-40

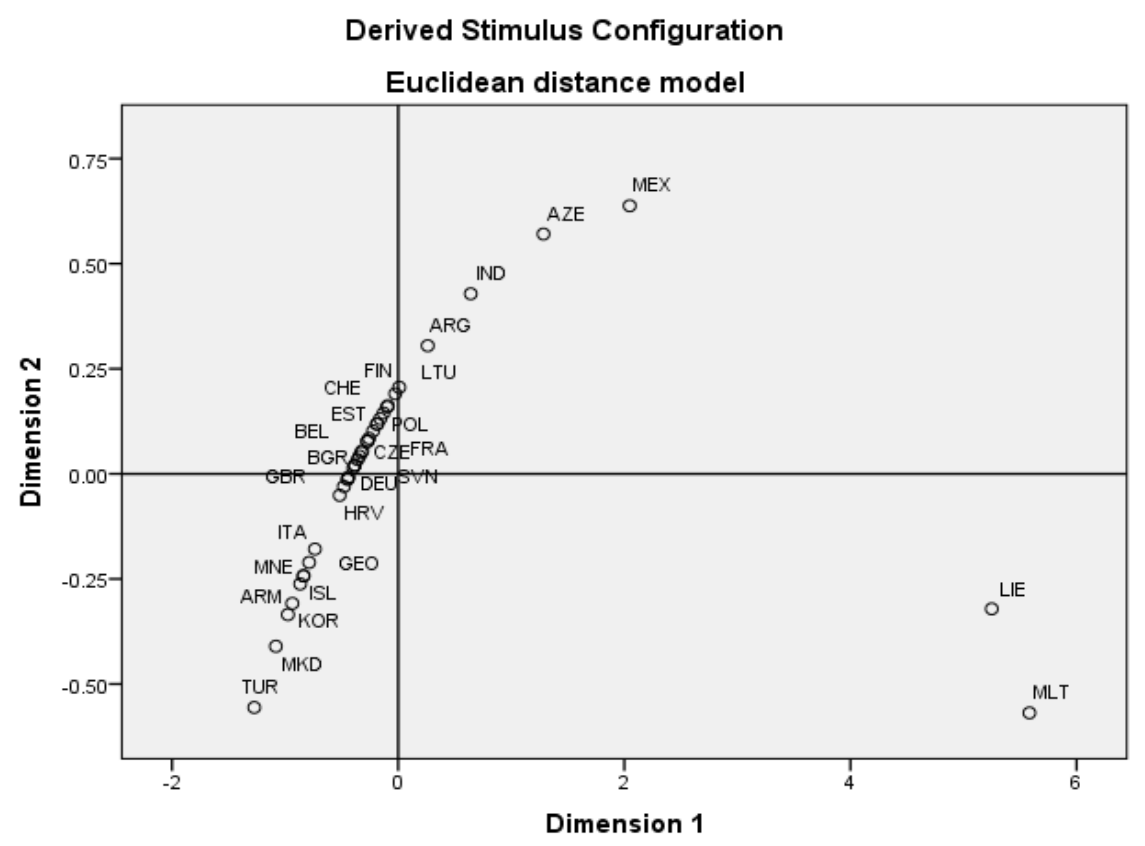

Figure 4. Linear Relation between Distances and Differences

When Figure 4 is examined, it is seen that similar OECD countries are gathered together. As a result of the MDS analysis examined in Figure 5, it is seen that countries are collected in three different groups in two-dimensional space according to the traffic accident indicators of interest. While Liechtenstein, Malta emerges in a separate group, and Turkey, Macedonia, Korea, Iceland, Armenia, the Republic of Montenegro, Italy, Georgia, Croatia, Germany emerge in another group, and the rest of the countries emerges as another group.

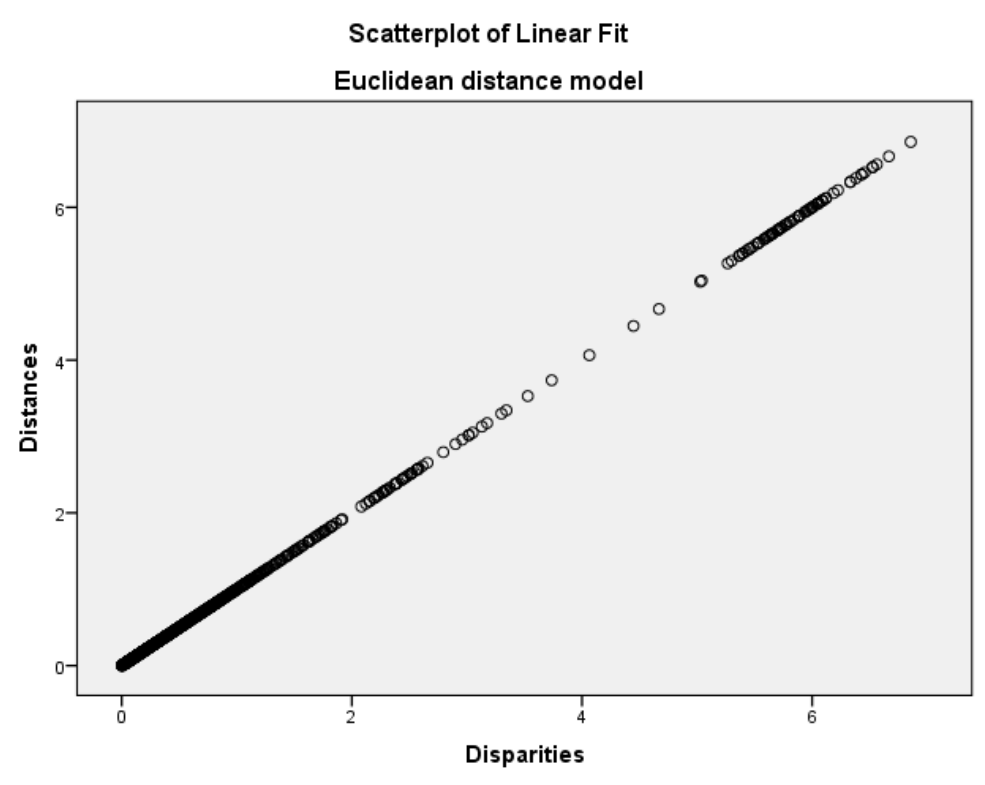

Figure 5. Euclidean Distance Model

When Figure 5 is examined, it is determined that the number of dimensions and distances and the differences are in a linear relationship. 
Int. J. of Health Serv. Res. and Policy (2020) 5(1): 24-40

\section{Conclusions and Recommendations}

In this study, it is aimed to examine the position of 39 OECD member countries in terms of traffic accident indicators and to reveal the similarities or differences between countries with Multivariate Statistical Techniques, which is one of the Multidimensional Scaling Techniques. As a result of the analysis, it is seen that the OECD countries are similar to each other in three-dimensional locations in two-dimensional space. In the first dimension; Liechtenstein and Malta are the most important parsers and appear to be in a very different position from other countries. In the second dimension, countries do not have positive load values above 1. However, Mexico, which has a value of 0.6378 as the positive value closest to 1 , can be considered the most important parser for this dimension. It is seen that Liechtenstein and Malta are similar, but appear to be taking place at a location different from other countries. It is seen that Turkey, Macedonia, Korea, Iceland, Armenia, the Republic of Montenegro, Italy, Georgia, Croatia, and Germany are similar to each other and form a separate group, while the rest are located in a different group. When the differences matrix is examined; it is understood that Turkey and Malta are the most different countries from each other among the OECD countries.

It is obvious that traffic accidents, a global public health problem, have a huge impact on individuals and communities and national economies. The countries especially, those which take place on the top with regard to the traffic accident indicators, such as the US, Japan, India, Germany, Korea, and Turkey should come together and confront this problem and develop national and international projects. In addition, taking serious measures on a local basis (infrastructure services, increasing traffic fines, and training, etc.) will help minimize human and economic losses. Thanks to these measures, reducing traffic accidents, which are among the most important causes of death in our country and some other countries, will have a positive effect on both individual and public health.

The compliance to the Research and Publication Ethics: This study was carried out in accordance with the rules of research and publication ethics.

Ethical Process: Ethics committee approval is not required for this study.

\section{References}

[1] Erjem, Y., " A Sociological Research on Traffic System Operation and Traffic Accidents”, Polis ve Sosyal Bilimler Dergisi, 3, 69-94, 2005.

[2] Alp, S., Engin, T., "Analysis and Evaluation of the Relation Between the Reasons and Consequences of the Traffic Accidents by using TOPSIS And AHP Methods", İstanbul Ticaret Üniversitesi Fen Bilimleri Dergisi, 10, 65-87, 2011.

[3] Sungur, İ., Akdur, R., Piyal, B., "Analysis of Traffic Accidents in Turkey", Ankara Med J, 14, $114-124,2014$.

[4] Kuşkapan, E., Alemdar, K.D., Kaya, Ö., Çodur, M.Y.,"Traffic Accidents Caused by Pedestrians in Turkey", International Journal for Traffic and Transport Engineering, 9(1), 118 - 126, 2019.

[5] Tortum, A., Çodur, M.Y., Kılınç, B., "Modeling Traffic Accidents in Turkey Using Regression Analysis", Iğdır Univ. J. Inst. Sci. \& Tech, 2(3), 69-78, 2012.

[6] Çodur, M.Y., Tortum, A., "An artificial neural network model for highway accident prediction: a case study of Erzurum, Turkey", Promet - Traffic\&Transportation, 27 (3), 217-225, 2015.

[7] Erdoğan, S., "Explorative spatial analysis of traffic accident statistics and road mortality among the provinces of Turkey", Journal of Safety Research, 40 (2009), 341-351, 2009. 
Int. J. of Health Serv. Res. and Policy (2020) 5(1): 24-40

[8] Eşiyok, B., Korkusuz, İ., Canturk, G., Alkurt Alkan, H., Gokmen Karaman, A., Hanc1, I.H., "Road traffic accidents and disability: A cross-section study from Turkey", Disability and Rehabilitation, 27(21), 1333-1338, 2005.

[9] Acar, F., Asirdizer, M., Aker, R.Z., Küçükibrahimoğlu, E.E., Ateş, İ., Erol, Y., Şahin, A., “A review of suspected cases of driving under the influence of drugs (DUID) involved in traffic accidents in Istanbul (Turkey)", Journal of Forensic and Legal Medicine, 20 (2013), 626-631, 2013.

[10] Aygencel, G., Karamercan, M., Ergin, M., Telatar, G., "Review of traffic accident cases presenting to an adult emergency service in Turkey", Journal of Forensic and Legal Medicine, 15(2008), 1-6, 2007.

[11] WHO, https://www.who.int/news-room/fact-sheets/detail/the-top-10-causes-of-death, 2018.

[12] OECD Road Accident data, https://data.oecd.org/transport/road-accidents.htm, 2018.

[13] Karacasu, M., Ergül, B., Altın Yavuz, A.," Estimating the causes of traffic accidents using logistic regression and discriminant analysis", International Journal of Injury Control and Safety Promotion, 21 (4), 305-312, 2014.

[14] Türkiye İstatistik Kurumu, Ulaşım İstatistikleri, 2017.

[15] Kırmızıoğlu, E., Tuydes Yaman, E.,"Comprehensibility of traffic signs among urban drivers in Turkey", Accident Analysis of Prevention, 45(2012), 131-141, 2011.

[16] Çelik, A.K., Oktay, E., "A multinominal logit analysis of risk factors influencing road traffic injury severities in the Erzurum and Kars Provinces of Turkey", Accidents Analysis and Prevention, 72(2014), 66-77, 2014.

[17] Karayolları Genel Müdürlügü, Trafik Kazaları Özeti 2017, (2018). www.kgm.gov.tr.

[18] Bektaş, S., Hınıs, M.A., "Şehiriçi trafik kazalarına etki eden faktörlerin lojistik regresyon modeli ile incelenmesi: Aksaray örneği”, J. Fac.Eng.Arch. Selcuk Univ., 23 (3), 25-34, 2008.

[19] Murat, Y.Ş., Şekerler, A.,’Trafik Kaza Verilerinin Kümelenme Analizi Yöntemi ile Modellenmesi. IMO Teknik Dergi, 2009, 4759-4777, 2009.

[20] Eygü, H., "Trafik kazalarını etkileyen faktörlerin yapısal eşitlik modeli ile incelenmesi”, Elektronik Sosyal Bilimler Dergisi, 17(66), 838-851, 2018.

[21] Cansız, Ö.F., “Türkiye'de trafik kazalarında meydana gelen ölü sayısı tahmin modellerinin geliştirilmesinde logaritmik regresyon ve yapay sinir ağları metotlarının kullanılması", Karaelmas Fen ve Mühendislik Dergisi, 8(2):446-453, 2018.

[22] Tercan, E., Beşdok, E., “Trafik Kazalarına Etki Eden Faktörler Arasındaki İlişkilerin TBA Biplot Analiz Yöntemi İle Değerlendirilmesi”, Iğdır Univ. J. Inst. Sci. \& Tech. 8(1), 103-111, 2018.

[23] Tercan, E., Beşdok, E., Tapkın, S., "Heuristic Modelling of traffic accident characteristics", Transportation Letters, 1-9, 2020.

[24] Uçar, Ö., Tatlıdil, H., "Factors influencing the severity of damage in bus accidents in Turkey during 2002: an application of the ordered probit model", Hacettepe Journal of Mathematics and Statistics, 36(1), 79-87, 2007.

[25] Acı, Ç, Yılmaz, A.C., "Maddi hasarlı trafik kazaları için sinirsel-bulanık ağ tabanlı bir kusur tespit modeli", Science and Eng. J of Firat Univ., 29(2), 241-250, 2017.

[26] Arı, E., "Trafik kaza verilerinin log lineer modeller ile incelenmesi”, Suleyman Demirel University The Journal of Faculty of Economics and Administrative Sciences, 21(1),17-37, 2016.

[27] Güler, H., "Karayolu trafik kazalarına yeni bir yaklaşım: Kaza analiz kesimleri modeli", Pamukkale University Journal of Engineering Sciences, 23(6), 707-717, 2016. 
Int. J. of Health Serv. Res. and Policy (2020) 5(1): 24-40

[28] Doğrul, G., Akay, D., Kurt, M., “Trafik kazalarının birliktelik kuralları ile analizi”, Gazi Journal of Engineering Sciences, 1/2(2015), 265-284, 2015.

[29] Söylemez, İ., Doğan, A., Özcan, U., “Trafik Kazalarında Birliktelik Kuralı Analizi: Ankara İli Örneği”, Ege Academic Review. 16• Özel Say1 • 2016, 11-20, 2016.

[30] Page, Y., "A statistical model to compare road mortality in OECD countries", Accident Analysis \& Prevention, 33 (3), 371-38, 2001.

[31] Gaygisiz, E., "Economic and Cultural Correlates of Road-Traffic Accident Fatality Rates in OECD Countries", Perceptual and motor skills, 2009. 109 (2), 531-545, 2009.

[32] Tokuçoğlu, T., Algılama haritalarının hazırlanmasında Çok Boyutlu Ölçekleme yöntemi. Gazi Üniversitesi Sosyal Bilimler Enstitüsü, Yüksek Lisans tezi, 2008.

[33] Gürçaylılar Yenidoğan T., "Multidimensional scaling in marketing research: a study on university students' perceptions of brand", Akdeniz University Journal of Economics and Administrative Sciences, 8, 138-69, 2008.

[34] Büyüker İşler, D.. "Examining between regional internal migration movements in Turkey with multidimensional scaling”, Adıyaman Üniversitesi Sosyal Bilimler Enstitüsü Dergisi, 7, 447-484, 2014.

[35] Ekiyor, A., Algılama haritalarının hazırlanmasında Çok Boyutlu Ölçekleme tekniğinin kullanılması: Ankara İli Özel Hastaneler Örneği. Gazi Üniversitesi Sosyal Bilimler Enstitüsü, doktora tezi, 2009.

[36] Ersöz F., "Analysis of health levels and expenditures of Turkey and OECD countries", İstatistikçiler Dergisi, 1,95-104, 2008.

[37] Acar, A.B., "Comparison of Turkey and the Other OECD Countries in Terms of Labour Markets' Main Indicators Using Multi Dimensional Scale Analysis", Faculty of Business Administration Institute of Business Administration Journal of Management 24, 121-144, 2013.

[38] Tüzüntürk S., "Multidimensional scaling: an application on crime statistics", Uludağ University Journal of Economics and Administrative Sciences, 28,71-91, 2009.

[39] Etikan, İ., Erkorkmaz, Ü., Sanisoğlu, S.Y., Demir, O., Kuyucu, Y.E., "Multidimensional Scaling analysis of Judicial Statistics for Crimes Against Persons and Properties in 2008 in 81 Provinces in Turkey", Türkiye Klinikleri J Med Sci, 32, 1295-1306, 2012.

[40] Ersöz, T., Türkoğlu Elitaş MN., Ersöz, F., "Investigation of Multidimensional Scaling Analysis of Biomass Energy Generation in OECD Countries", TÜBAV Bilim, 8, 1-11, 2015.

[41] İhtiyaroğlu, F., Çok Boyutlu Ölçekleme analizi ve uygulaması. İstanbul Ticaret Üniversitesi Fen Bilimleri Enstitüsü, Yüksek Lisans tezi, 2012.

[42] Akın, H.B., Eren, Ö., “OECD ülkelerinin eğitim göstergelerinin Kümeleme analizi ve Çok Boyutlu ölçekleme analizi ile karşılaştırmalı analizi”, Öneri Dergisi, 10(37), 175-181, 2012.

[43] Özdamar K., Multi-Dimensional Scaling. Paket Programlar ile İstatistiksel Veri Analizi 2 (Çok Değişkenli Analizler). 5. Baskı. Kaan Kitabevi, 2004.

[44] Gündüz, S., Uzaklık fonksiyonlarının Çok Boyutlu Ölçekleme algoritmalarındaki etkinliğinin incelenmesi ve uygulamalar. Çukurova Üniversitesi Yüksek lisans tezi, 2011.

[45] Bülbül, S., Köse, A., “Türkiye'de bölgelerarası iç göç hareketlerinin çok boyutlu ölçekleme yöntemi ile incelenmesi”, İstanbul Üniversitesi İşletme Fakültesi Dergisi, 39, 75-94, 2010.

[46] İbicioğlu, M., "Multidimensional Scaling Analysis of Relations Among Returns of Investment Instruments", The International Journal of Economic and Social Research, 8, 8:45-55, 2012.

[47] Alpar, R., Uygulamalı Çok Değişkenli İstatistiksel Yöntemler. Detay Yayıncılık, 2013. 
Int. J. of Health Serv. Res. and Policy (2020) 5(1): 24-40

[48] Aydın, D., Başkın B., "The Classification Structures of Banks by Their Capital Adequacy Ratios as the Results of Clustering Analysis and Multidimensional Scaling", BSAD Bankacilık ve Sigortacılık Araştırmaları Dergisi, 1, 29-47, 2013.

[49] Tinsley, H.E. A. Brown, S.D., Handbook of Applied Multivariate Statistics and Mathematical Modeling. Academic Press, 2000.

[50] Firat, Ü.O., Demirhan, A., "Performance Analysis of Commercial Banks", ODTÜ Iktisat Kongresi, Ankara, 2001.

[51] Johnson RA, Wichern DW., Multidimensional Scaling]. Applied Multivariate Statistical Analysis. 4th ed. New Jersey: Pearson Prentice Hall, 1999.

[52] Tatlıdil H., Multi-Dimensional Scaling Uygulamalı Çok Değişkenli İstatistiksel Analiz. 2. Baskı. Ankara: Akademi Matbaasi; 6. p.279-90, 1996.

[53] Oğuzlar, A.,"Locating factors affecting membership of European Union Using Multidimensional Scaling”, Uludağ University Journal of Economics and Administrative Sciences, 24, 33-43, 2005.

[54] Kruskal, J. B., "Multıdimensional Scaling By Optimizing Goodness Of Fit to a Nonmetric Hypothesis ", Psychometrika, 9(1), 1-27, 1964. 